\title{
Population Briefs, Vol. 11, no. 1
}

Population Council

Follow this and additional works at: https://knowledgecommons.popcouncil.org/ series_newsletters_popbriefs How does access to this work benefit you? Let us know!

\section{Recommended Citation}

Population Briefs 11(1): New York: Population Council, 2005. 


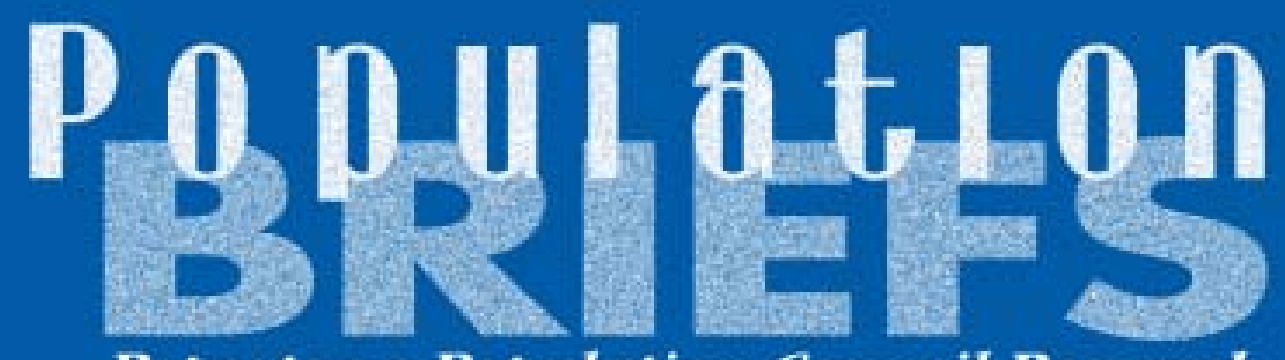

Reports on Population Council Research

January 2005

Volume 11, Number 1

MATERNAL AND CHILD HEALTH

\section{Mixed Success Involving Men in Maternal Care Worldwide}

In most locales around the world, whether in developing or developed countries, men are little involved in their partners' health care during pregnancy. Research has shown, however, that women would like their partners to be more involved and that, in many cases, men are interested in being involved. Increased male participation could yield health benefits for men, women, and children. In recognition of this situation, the Population Council's Frontiers in Reproductive Health program conducted two "Men in Maternity" studies in disparate settings — one in India and the other in South Africa - to engage male partners in health services during the antenatal and postpartum periods. Although the intervention in India was more successful than the one in South Africa, valuable lessons were learned in both countries.

\section{India}

In India, women depend heavily on men for access to health care. Men are the key decisionmakers regulating women's access to health care services even though they have limited knowledge on this matter. Between 2000 and 2003, the Population Council and the Employees' State Insurance Corporation (ESIC) of India conducted the Men in Maternity study at six of ESIC's Delhi clinics, assigning three to carry out the intervention and three to act as controls. At the experimental clinics, women and their husbands received joint counseling on pregnancy care, family planning, and infant care, and same-sex individual or group counseling on sexually trans- mitted infections (STIs), correct condom use, and other topics. They also received antenatal testing and, if necessary, treatment for syphilis. Couples were seen during the pregnancy and at six weeks postpartum. At control clinics, pregnant women received standard care, which included very little counseling on pregnancy danger signs, family planning, or other reproductive health issues.

\section{"Involving men in}

maternal care is feasi-

$$
\text { ble and acceptable." }
$$

A total of 581 pregnant women at experimental clinics and 486 at control sites were interviewed when they came for their first antenatal visit. Follow-up interviews were conducted in couples' homes at six months postpartum: 327 women and their husbands from the intervention group and 302 women and their husbands from the control group were interviewed at this time.

The postintervention survey showed that couples in the experimental sites communicated significantly more about family planning (84 percent versus 64 percent) and reported more joint decisionmaking on the issue (91 percent versus 71 percent) than did couples attending the control clinics. Use of family planning by women and men six months postpartum was also significantly higher in the intervention sites. Significantly more men in the intervention group knew that condoms provide protection from both STIs and pregnancy. Gender-based disparities remained: twice as many men as women in the experimental group knew of the dual protection provided by condoms (89 percent versus 48 percent).

"Involving men in maternal care is something that couples want, both women and men," says Council researcher Leila Caleb Varkey, who worked on the Indian intervention. "Men take more contraceptive responsibility if they have adequate information and counseling about condoms. Our research shows that it's possible in crowded clinics to integrate services for men and women. Both clients and providers appreciate the time spent in counseling."

According to ESIC, expenditures on the reproductive health intervention were feasible and affordable, consisting mainly of purchases of supplies and materials. No new staff members were required and changes in staff routines were possible without increasing work hours.

ESIC has expanded the program to ten clinics since the study ended and plans to extend it to its 34 clinics and five hospitals in Delhi by 2005. The Frontiers in Reproductive Health program is providing technical assistance to improve ESIC's training and supervisory capacity and will monitor and evaluate the program's progress for one year.

\section{South Africa}

According to UNAIDS, HIV testing at antenatal clinics has demonstrated a consistent and sharp increase in infection among pregnant 


\section{Bengali Perceptions of Adult Mortality Trends Distorted}

Nostalgia for the "good old days," a familiar sentiment in the developed world, may be common in the developing world as well. Recent research in Bangladesh and the Indian state of West Bengal has revealed that, despite well-documented progress in health and an acknowledged improvement in child mortality rates, many rural Bengalis firmly believe that adult health and survival have declined in recent years. Demographers Sajeda Amin, of the Population Council, and Alaka Malwade Basu, of Cornell University, encountered this attitude while conducting interviews on women's and men's motivations for reproduction. They were intrigued and decided to further explore this surprising worldview.

The data analyzed in this study were drawn from a larger study of reproductive change. The researchers conducted 32 focusgroup discussions, each with six to ten rural respondents of the same sex and religion, in nine rural districts (four in Bangladesh and five in West Bengal).

\section{Contradictory perceptions}

Data from the World Health Organization show that between 1901 and 2000 in Bangladesh and West Bengal, death rates declined and life expectancy increased for every age group. Respondents unanimously agreed that child mortality had fallen dramatically in recent times. They pointed to several reasons for improved child survival: immunization against childhood diseases, antitetanus vaccination for pregnant mothers, the expansion of medical care facilities for women and children, door-to-door service delivery by health care workers, and a move to treat childhood ailments with modern medicine rather than traditional healing practices.

In virtually every interview the researchers conducted, however, they found that the respondents believed that adults today die earlier than they did in their fathers' and grandfathers' time. Nearly all the respondents identified a decline in food quality and quanti- ty, along with population growth and moral degeneration, as causes for this drop in longevity.

The respondents stated that because of population growth, less food is available than in the past. Food is also less healthful now because it is produced for the market rather than for subsistence. Hence, it is grown with less care and with poisonous fertilizers and

\section{More important than}

the reasons for this

outlook are its possible

consequences.

pesticides. Furthermore, the lifestyle required for producing marketable food leads to stress, which in turn leads to illness and such risky behaviors as drug abuse, contended respondents. In the past, interviewees asserted, people were more God-fearing and pious. The past was not just a time of abundant, healthful food; it was also a time when people were "good."

The researchers point to several possible explanations for this outlook. Memories of famines and disease epidemics could have contributed to a general perception that survival is threatened. Or, the bare subsistence experienced by many respondents could compare poorly with the lifestyle of abundance and indulgence depicted in local folklore and mythology. Improvements in skill with numbers and mathematics may account for some of the feeling that people are not living as long as in the past. Today, if a recently deceased man is known to have been 60 years old at his death, he will be thought to have died young in comparison to his forebears who are believed incorrectly to have lived to be 80,90 , and 100 .
Finally, the moral decline often mentioned by respondents suggests that apprehensions about modern lifestyles may explain the perceived increase in adult mortality. Children are too young to be held morally accountable. Therefore, it is justifiable to appreciate the survival advantages that modernity has afforded them. But the moral degeneration of adults can only be endured if it is accompanied by some kind of punishment, such as decreased survival.

\section{Consequences of this outlook}

More important than the reasons for this outlook, however, are its possible consequences, says Amin. The perception of an uncertain future could have a variety of influences on people's behavior. Researchers need to investigate these potential consequences more fully. The contrasting perceptions of the prospects for child and adult survival, for example, may have helped sustain fertility decline. "If more children are expected to survive to maturity, parents can afford to have fewer offspring," explains Basu. "And if people do not expect to live as long as their forefathers did, they may also be less concerned about having children to support them in their old age."

This worldview may also influence the way that women and children are treated in society. "On the one hand, if people believe they have little to lose, they may be more permissive with women and children and allow riskier behavior," says Amin. "On the other hand, if people think the world is more risky and 'bad,' they may be more protective and less apt to give women and children freedoms."

SOURCE

Amin, Sajeda and Alaka Malwade Basu. 2004.

"Popular perceptions of emerging influences on mortality and longevity in Bangladesh and West Bengal," Population Studies 58(3): 357-363 (also published as Policy Research Division Working Paper no. 186. New York: Population Council, http://www.popcouncil.org/pdfs/wp/186.pdf).

OUTSIDE FUNDING

The Rockefeller Foundation 


\section{Unsafe Behaviors Most Common among Poor Women}

Around the world, HIV infects about 1 percent of 15-24-year-olds, but in KwaZulu-Natal, South Africa, more than 14 percent of people in this age group are infected, according to a 2003 population-based survey by Lovelife and the Reproductive Health Research Unit in Johannesburg. Young women are at particularly high risk of infection. South Africa has three infected 15-24-year-old females for every infected male of the same age. Poverty may play a key role in HIV risk. Approximately 57 percent of people in South Africa were living below the poverty income line in 2001, according to the Southern African Regional Poverty Network. Population Council health economist Kelly Hallman investigated the effect of socioeconomic disadvantage on the sexual behaviors of young women and men in KwaZulu-Natal, the most populated South African province. Hallman is a member of the Council's "Transitions to Adulthood in the Context of AIDS in South Africa" study team. She found that poverty is more consistently correlated with unhealthy sexual behaviors among females than among males.

The team studied two districts within KwaZulu-Natal: Durban Metro and Mtunzini Magisterial District. These districts represent the spectrum between urban and rural areas. The team surveyed all willing young people aged 14-24 years within these districts, using interviewers who were the same ethnicity, gender, and general age as the respondents. The investigators asked young people about many aspects of their lives, including schooling, work, sexual and reproductive health behaviors, HIV/AIDS knowledge, childbearing, and marriage. Researchers also talked to heads of households, usually parents, about family composition, living conditions, economic status, and HIV/AIDS attitudes. "Transitions to Adulthood in the Context of AIDS in South Africa" was the first panel study in South Africa to focus on adolescents.

\section{Poverty, gender, and sexual behavior}

Hallman found that economic disadvantage significantly affected a number of sexual behaviors and experiences of young females and males, and that the behavior of young women was more substantially influenced by poverty than was the behavior of men.

"When discussing risky sexual behaviors that might be influenced by low socioeconomic status, many people think only of exchanging sex for money, goods, or favors," says Hallman. "The data show, however, that a wide range of risky behaviors is affected by poverty." Although being from a poorer household does increase the likelihood of a young woman's exchanging sex, Hallman's analysis showed that it also raises her chances of experiencing nonconsen-

"Poor young women

need strategies for

building economic

and social assets."

sual sex. Poverty increases young women's chances of having multiple sex partners. It lowers a young woman's chances of abstinence following earlier sexual encounters and condom use at last sex and reduces the age at which young men and women have their first sexual encounter. It also increases the risk of early pregnancy.

The data show that impoverished young people, especially young women, are the most disadvantaged in discussing sensitive topics, such as condom use, with their sexual partners. The study suggests that this situation may result from a lack of negotiating skills. Analysis of these data by other members of the team showed that only 82 percent of low-resourced schools, versus 92 and 97 percent of mediumand high-resourced schools, had at the time implemented a government-mandated "life skills" program, of which negotiation skills are a key component.
Higher levels of education among members of the household generally decrease the odds of risky sexual behavior, particularly the chances that a young woman will exchange sex or experience forced sex. Looking at other variables, Hallman found that poverty was more important than orphanhood in influencing risky sexual behaviors.

The study revealed that poorer young women and men — but particularly young womenhad less access to television, radio, publications, and other media sources that might contain family planning or safe sex messages.

"Even with information and good communication skills, young people living in underprivileged settings may still be more likely to find themselves in situations that are conducive to high-risk behavior," says Hallman. Investigations by other researchers, for example, have shown that when women in South Africa raise the topic of condom use with a sexual partner, they risk emotional, physical, and "economic" abuse. In this setting, many sexual relationships provide economic security. Poor young women may have much to lose by raising such sensitive issues.

Hallman found that gender and income have crucial influences on behavior: the negative effects of poverty were often larger and of greater statistical significance for females than males. "Enhancing poor young women's negotiation and communication skills is a starting point," explains Hallman, "but they also need strategies for building economic and social assets so they are in stronger bargaining positions within relationships."

\section{SOURCE}

Hallman, Kelly. 2004. "Socioeconomic disadvantage and unsafe sexual behaviors among young women and men in South Africa," Policy Research Division Working Paper no. 190. New York: Population Council.

\section{OUTSIDE FUNDING}

The Rockefeller Foundation, the U.K. Department for International Development, and the U.S. Agency for International Development (through the Horizons Project, the Focus on Young Adults Project, the Measure-Evaluation Project, and the Office of Population, Bureau for Global Health) 


\section{Maternal Health Education Needed in Pakistan}

The period of time after a woman gives birth, during which her uterus shrinks and other physical changes that occurred during pregnancy are reversed, is a crucial yet underresearched element of maternity. Although the pregnancy has ended, serious diseases or disabilities associated with pregnancy — such as infection or heavy bleeding — are still possible. In fact, some traditional practices may increase the likelihood of these maladies. Similarly, the neonatal period is critical for infants, and some traditional practices may put their health at risk as well. Population Council researchers Fariyal F. Fikree (director, regional health programs, Cairo office) and Jill M. Durocher collaborated with Tazeen Ali of the Aga Khan University and Mohammad H. Rahbar of Michigan State University to study these topics. They explored postpartum and neonatal health, traditional beliefs and practices, and care-seeking behaviors among new mothers in poor areas of Karachi, Pakistan.

The investigators combined qualitative and quantitative research methods. In July and August 2000, they conducted five focus-group discussions of eight to ten participants each and 15 in-depth interviews. Women in the focus-group discussions and those who were interviewed were young and older postpartum mothers, those who had many children and those who had only one, and trained and untrained traditional birth attendants. From August to November 2000, the researchers also conducted a survey among 525 Muslim women who were six to eight weeks postpartum in five impoverished settlements in Karachi, Pakistan.

\section{Postpartum bealth}

The investigators found that maternal care was adequate; more than three-quarters of recent mothers sought antenatal care, and more than half delivered their babies in a hospital or maternity home. Only 16 percent of women who had delivered their babies in a health care facility had been counseled to attend a postpartum clinic, however. of these, only 26 percent actually attended.
The most clinically significant symptoms during the immediate postpartum period, heavy vaginal bleeding and high fever, are potentially fatal if women do not receive appropriate and timely care. About half of the women in the study reported at least one symptom of illness, with 21 percent experiencing high fever, 14 percent having heavy vaginal bleeding, and nearly 10 percent reporting foulsmelling vaginal discharge (see Table 1). Women did not know the underlying biological cause of their ailments; they frequently attributed them to "weakness."

\section{Traditional practices}

The researchers also discovered that traditional practices that might cause infection or exacerbate bleeding were common during the delivery and recovery. For example, women described traditional birth attendants massaging the vaginal walls with mustard oil during labor to ease delivery. Nearly 18 percent of women said that in order to facilitate uterine shrinkage or to prevent infection, family members or birth attendants had prepared herbal powders or sticks for insertion into the vagina or rectum. Additionally, although many new mothers are concerned by heavy vaginal bleeding, elders and traditional birth attendants often perceive such bleeding as beneficial. They believe that menstrual blood, which they consider impure, is retained during pregnancy and released afterward. Thus, they encourage new mothers to eat foods that are thought to increase postpartum bleeding.

\section{Care-seeking behaviors}

Women generally sought care initially from close relatives or traditional healers. However, if they continued to suffer, they eventually approached a Western-trained health care provider. One woman described her experience, "I first went to the dai [traditional birth attendant] for a massage for body pain. Then I went to a holy man for holy medication. Eventually everyone goes to the doctor to be cured."

\begin{tabular}{|c|c|c|}
\hline \multicolumn{3}{|c|}{$\begin{array}{l}\text { Table } 1 \text { Descriptive frequency of } \\
\text { symptoms among } 280 \text { recently } \\
\text { delivered women reporting a } \\
\text { perceived morbidity during the } \\
\text { puerperium (low socioeconomic } \\
\text { settlements, Karachi, Pakistan, 2000) }\end{array}$} \\
\hline Symptoms ${ }^{a}$ & $(n)$ & $(\%)$ \\
\hline Backache & 61 & 21.8 \\
\hline High fever & 59 & 21.1 \\
\hline Fever & 58 & 20.7 \\
\hline Heavy vaginal bleeding & 39 & 13.9 \\
\hline Low abdominal pain & 36 & 12.9 \\
\hline Weakness & 34 & 12.1 \\
\hline $\begin{array}{l}\text { Vaginal discharge } \\
\text { (foul-smelling) }\end{array}$ & 27 & 9.6 \\
\hline Anemia & 23 & 8.2 \\
\hline Severe headache & 18 & 6.4 \\
\hline Dizziness & 14 & 5.0 \\
\hline High blood pressure & 5 & 1.8 \\
\hline Infection in tears/stitches & 4 & 1.4 \\
\hline Others $^{b}$ & 44 & 15.7 \\
\hline \multicolumn{3}{|c|}{$\begin{array}{l}\text { 'Multiple responses; does not add to } 100 \% \text {; } \\
\text { some women reported symptoms of more } \\
\text { than one illness. } \\
\text { 'Others include: unspecified others, perineal } \\
\text { pain, constipation, body pain, urinary burning, } \\
\text { tiredness, uterine prolapse, uterine infection, } \\
\text { low blood pressure. } \\
\text { Source: Fikree et al. } 2004 \text {. }\end{array}$} \\
\hline
\end{tabular}

Delays in seeking appropriate care may stem from the common belief that certain symptoms are not only normal but desirable. Similarly, "many women believe that heavy vaginal bleeding and foul-smelling vaginal discharge occur from weakness caused by the rigors of labor and delivery and should therefore be endured," states Fikree. The delay in careseeking might be compounded, the researchers said, by male-dominated decisionmaking. More than 85 percent of women in the study sample said that they could decide to visit a clinic for a sick child or for themselves. However, study participants' answers to other key questions indicate that they may not have the freedom necessary to complete this task. Nearly 65 percent said that they needed to get permission to visit a clinic, especially for themselves, and more than 
78 percent reported that they needed permission to travel in a bus or rickshaw.

\section{Feeding the newborn}

The investigators also asked women about practices used in the care and feeding of their newborns. In Pakistan and other areas of South Asia, routine care of the newborn, including traditional feeding, bathing, and cord care practices, may prove harmful.

The majority of women - 55 percentfed their children initially with traditional substances such as honey, ghutti (an herbal paste), water, green tea, or other foods (see Table 2). Studies have shown that breast milk is the best first food for babies and that such "prelacteals" may be harmful to infants. Honey, for example, may contain the dormant spores of a bacteria that causes a rare but very serious condition called infant botulism.

The vast majority of mothers, 99 percent, went on to breastfeed their newborns regularly, with 14 percent of mothers introducing breastfeeding within the first half hour and nearly 30 percent within the first hour after birth. Nearly 8 percent of newborns, however, were not breastfed for two or more days after birth. And 71 percent of mothers supplemented their infants' regular food with the traditional substances listed above.

Mothers had various reasons for these feeding practices. For example, one mother said that she gave her newborn water mixed with sugar and salt so that the baby would urinate frequently. "By urinating, the heat inside the baby's body is released and then the baby feels hungry. This is necessary for the newborn's health." Ghutti and honey are thought to reduce colic and gastrointestinal problems. Another mother explained, "Ghutti helped to clean the stomach, released the pain, and allowed the stool to be passed." Some consider withholding breast milk for the first few days to be beneficial because of a perceived impurity in the breast milk. "My mother-in-law said that the first milk is dirty because it has been stagnant for nine months. So, I let this milk come out, and I gave my baby buffalo milk with a bit of water mixed in it for three days," said one mother.

The researchers noted the success of mass media educational campaigns in promoting breastfeeding. A traditional birth attendant told

Table 2 Descriptive frequency of traditional newborn-care practices among 515 mothers (low socioeconomic settlements, Karachi, Pakistan, 2000)

\begin{tabular}{lcccc} 
Traditional newborn-care practices & Yes (\%) & $(\boldsymbol{n})$ & No (\%) & $(\boldsymbol{n})$ \\
\hline Give prelacteals as first feed & 55.0 & $(283)$ & 45.0 & $(231)$ \\
Delay first feed & 30.9 & $(159)$ & 69.1 & $(356)$ \\
Give supplementary feeds & 71.3 & $(367)$ & 28.7 & $(148)$ \\
Bathe immediately after birth ${ }^{\text {b }}$ & 82.1 & $(416)$ & 17.9 & $(91)$ \\
Massage with mustard oil & 67.8 & $(349)$ & 32.2 & $(166)$ \\
Instill nasal/ear drops & 28.2 & $(145)$ & 71.8 & $(370)$ \\
Apply traditional substances to cord & 57.3 & $(295)$ & 42.7 & $(220)$ \\
${ }^{a} n=514 ;$ missing information for one woman. & & & & \\
${ }^{\mathrm{b}} n=507 ;$; excludes 8 women who replied "don't know." & & & & \\
Source: Fikree et al. 2005. & & & & \\
\hline
\end{tabular}

the investigators, "Now they say on television that one should give breast milk to the baby. So, we tell the women that doctors have told us that the child should receive mother's milk first of all."

\section{Caring for the newborn}

Certain traditional care practices may be harmful for the baby. Nearly 87 percent of mothers said that their infants were washed immediately or within a half hour of delivery, an action that can result in hypothermia, dangerously low body temperature. This was done to remove the vernix - the protective material that covers the skin of a fetus and is considered dirty or harmful. A large majority of women applied various substances to the umbilical stump to promote healing. A substantial minority used antiseptics or antibiotic ointments or powders, which are beneficial. More than half, however, treated the stump with mustard oil, coconut oil, surma (which contains antimony, a metallic element), or other traditional substances. When applied to an unhealed umbilical stump, these materials may lead to sepsis, a potentially deadly infection of the blood. Daily massage with mustard oil is another common newborn-care ritual that may induce sepsis.

On the basis of their findings, the researchers suggest that health care providers view antenatal care visits as opportunities to educate women about the biomedical causes of serious postpartum illnesses, such as heavy bleeding or high fever, and about benign and beneficial feeding and care practices for the newborn. Physicians can also use these visits as opportunities to encourage women to attend routine postpartum checkups.

However, Fikree and her colleagues contend, it is not appropriate or feasible to recommend interventions that depend entirely on the biomedical model. They suggest that their results have illustrated the fundamental role that traditional beliefs and practices play in the health-seeking and care-giving behaviors of new mothers in these areas of Pakistan. "We recommend that care givers help women to differentiate between benign and harmful practices. Total seclusion after childbirth may harm mothers and infants, for example, while rest is beneficial. Harmless traditional practices can be encouraged in counseling sessions and through information dissemination, and risky ones discouraged," says Fikree. "In this way we can maintain traditions in a healthier way." Women receive information from family members, elders, and traditional birth attendants, the investigators found, so these groups as well as pregnant women and mothers of newborns should be targeted with educational messages.

\section{SOURCES}

Fikree, Fariyal F., Tazeen S. Ali, Jill M. Durocher, Mohammad Hossein Rahbar. 2005. "Newborn care practices in low socioeconomic settlements of Karachi, Pakistan," Social Science \& Medicine 60(5): 911-921.

Fikree, Fariyal F., Tazeen Ali, Jill M. Durocher, and Mohammad H. Rahbar. 2004. "Health service utilization for perceived postpartum morbidity among poor women living in Karachi," Social Science \& Medicine 59(4): 681-694.

\section{OUTSIDE FUNDING}

The John D. and Catherine T. MacArthur Foundation 


\section{Maternal and Child Health}

continued from page 1

women tested between 1997 and 2003, with 28 percent of pregnant women in South Africa testing HIV-positive by the latter date. Although women are increasingly tested for HIV at antenatal clinics, men rarely seek reproductive health and HIV-testing services. Moreover, certain sexual practices during and after pregnancy may increase HIV risk. Many women, for example, abstain from sex before and after delivery. During this time, men may have other partners. "Involving men in maternal care in South Africa could provide opportunities for men and women to discuss reproductive health and learn about HIV risks in a setting mediated by a health care provider," explains Busi Kunene, intervention researcher from the University of Witwatersrand's Reproductive Health Research Unit.

Instituting this program in South Africa-where the Population Council collaborated with the Reproductive Health Research Unit, the KwaZulu-Natal Department of Health, and Family Health International — posed challenges unlike those in India. At the clinics used in India, which are affiliated with the men's workplaces, men frequently accompany their wives on their initial visits. It was at these visits that male partners were approached to participate in the intervention. The clinics used in the South Africa study had no affiliation with the male partners' workplaces, and men, when invited, often found it difficult to miss time at work to attend antenatal and postpartum appointments. Most of the women were not married to and did not live with their partners, thus making it more difficult to contact these men.

At the six experimental clinics in the South African province of KwaZulu-Natal, 995 women and 584 of their male partners were interviewed and enrolled in the intervention. At six control clinics, 1,087 women received services following current Department of Health practices and guidelines.

"Despite the obstacles, the project showed that involving men in maternal care is feasible and acceptable," says Population Council investigator Saiqa Mullick. "At least one-third of couples in the South African intervention attended counseling sessions. In this area prior to the intervention, it was extremely uncommon for men to attend sessions."

Additionally, women in the intervention group were significantly more likely than women in the control group to be assisted by their partners when they experienced difficulties in their pregnancies. The increase in knowledge about the dually protective nature of condoms was significantly higher among women attending intervention clinics compared with women at the control clinics. And a significantly higher proportion of intervention couples discussed such key issues as STIs, sexual relations, baby immunization, and breastfeeding. "The increase in communication is an important antecedent to behavior change," asserts Population Council researcher Emma Ottolenghi, who participated in both studies.

No other effects of the intervention were detected in South Africa. The researchers speculate that had the intervention been in place for a longer period or been supported by mass communication efforts to encourage men to come to the clinic, a more substantial transformation may have occurred. On the basis of the results of the Men in Maternity study and other studies in KwaZulu-Natal, the provincial Department of Health is revising its antenatal and postnatal care guidelines and developing new policies. Involving male partners has been identified as a key issue. Frontiers in Reproductive Health and the Reproductive Health Research Unit are collaborating with various agencies to develop the policies and guidelines.

\section{SOURCES}

Kunene, Busi, Mags Beksinka, Simphiwe Zondi, Nobuhle Mthembu, Saiqa Mullick, Emma Ottolenghi, Immo Kleinschmidt, Susan Adamchak, Barbara Janowitz, and Carmen Cuthbertson. 2004. "Involving men in maternity care: South Africa," Frontiers Final Report. Washington, DC: Population Council. Varkey, Leila Caleb, Anurag Mishra, Anjana Das, Emma Ottolenghi, Dale Huntington, Susan Adamchak, M.E. Khan, and Frederick Homan. 2004. "Involving men in maternity care in India," Frontiers Final Report. Washington, DC: Population Council.

OUTSIDE FUNDING

United States Agency for International Development

The Frontiers in Reproductive Health program is implemented by the Population Council in collaboration with Family Health International.

\section{Miss an issue of Population Briefs? Back issues are available free of charge while supplies last.}

\author{
All issues of Population Briefs are \\ available on the Population Council's \\ Web site: http://www.popcouncil.org/ \\ publications/popbriefs/default.htm
}

\section{In previous issues:}

Reproductive Health Program for Youth Successful in Kenya (September 2004) Door-to-Door Delivery of Family Planning Enhances Women's Status in Bangladesh (September 2004)

Bias Against Women in South Asia Shortens Lifespan (June 2004)

Making Public Pensions Sustainable (June 2004)

Carraguard ${ }^{\circledR}$ May Block HIV by Adhering to Cells (January 2004)

Schooling Trends in Africa: New Assessment

Methods Needed (January 2004)

Broad Survey of Pakistani Youth Completed (October 2003)

Unlocking the Mechanism of Androgen Action (October 2003)

Education Improves Breastfeeding Practices in Zambia (June 2003)

Hormone Choice May Reduce Risks of Menopause Therapy (June 2003)

Mirena ${ }^{\circledR}$-Induced Drop in Menstrual Bleeding Studied (February 2003) New Operations Research Handbook Targets HIV/AIDS (February 2003)

Maternal Deaths in the Dominican Republic Analyzed (September 2002)

What Factors Affect the Prevalence of HIV in sub-Saharan Africa? (July 2002)

For a cumulative index:

http:/www.popcouncil.org/publications/ popbriefs/pbindex.html

For more information or to order issues contact: Debra Warn, Office of Publications

Telephone: 212-339-0514

Fax: 212-755-6052

e-mail: dwarn@popcouncil.org 


\section{RECENT PUBLICATIONS}

\section{Biomedicine}

Ben-Chetrit, Avraham, Talia Eldar-Geva, Tzina Lindenberg, Morshed Farhat, Shlomo Shimonovitz, David Zacut, Hadassa Gelber, Régine Sitruk-Ware, and Irving M. Spitz. "Mifepristone does not induce cervical softening in non-pregnant women," Human Reproduction 19(10): 2372-2376

Bernard, Daniel J., Teresa K. Woodruff, and Tony M. Plant. "Cloning of a novel inhibin alpha cDNA from rhesus monkey testis," Reproductive Biology and Endocrinology 2(1): 71.

Bolino, Alessandra, Annalisa Bolis, Stefano Carlo Previtali, Giorgia Dina, Simona Bussini, Gabriele Dati, Stefano Amadio, Ubaldo Del Carro, Dolores D. Mruk, Maria Laura Feltri, C. Yan Cheng, Angelo Quattrini, and Lawrence Wrabetz. "Disruption of Mtmr2 produces CMT4B1-like neuropathy with myelin outfolding and impaired spermatogenesis," Journal of Cell Biology 167(4): 711-721.

Mruk, Dolores D. and C. Yan Cheng. "Cell-cell interactions at the ectoplasmic specialization in the testis," Trends in Endocrinology and Metabolism 15(9): 439-447.

. "Sertoli-Sertoli and Sertoli-germ cell interactions and their significance in germ cell movement in the seminiferous epithelium during spermatogenesis," Endocrine Reviews 25(5): 747-806.

Nash, Harold A., Dale N. Robertson, and Simone J. Evans. "Release-modulating factors strongly affecting steroid diffusion from silicone elastomer," Journal of Pharmaceutical Sciences 93(10): 2420-2430.

Sitruk-Ware, Régine. “New progestogens: A review of their effects in perimenopausal and postmenopausal women," Drugs and Aging 21(13): 865-883.

Sitruk-Ware, Régine, F. Husmann, S.O. Skouby, J.H.H. Thijssen, F. Fruzzetti, J. Hanker, J. Huber, and R. Druckmann. "Role of progestins with partial antiandrogenic effects," Climacteric 7(3): 238-254.

Sitruk-Ware, Régine and Genevieve Plu-Bureau. "Exogenous progestagens and the human breast," Maturitas 49(1): 58-66.

Siu, Michelle K.Y. and C. Yan Cheng. "Dynamic crosstalk between cells and the extracellular matrix in the testis," BioEssays 26(9): 978-992.

\section{Gender and Family Dynamics}

Amin, Sajeda. "Gender division of labor within the family: South Asia," in Suad Joseph (ed.), Encyclopedia of Women and Islamic Cultures. Leiden: Brill Academic, pp. $186-188$.

Amin, Sajeda and Nagah H. Al-Bassusi. "Education, wage work, and marriage: Perspectives of Egyptian working women," Journal of Marriage and Family 66(5): 1284-1296 (also published as Policy Research Division Working Paperno. 171. New York: Population Council, 2003).

“Bénin: Cibler les hommes pour accroître l'utilisation des services de santé" [Benin: Target men to increase use of health services], FRONTIERS OR Summary no. 18. Dakar: Population Council.

Erulkar, Annabel S. "The experience of sexual coercion among young people in Kenya," International Family Planning Perspectives 30(4): 182-189.
Finger, William, Shyam Thapa, Deepika Ganju, Shireen J. Jejeebhoy, Vijaya Nidadavolu, Iqbal Shah, and Ina Warriner. "Nonconsensual sex among youth," YouthLens no. 10. Washington, DC: Family Health International.

Ganju, Deepika, Shireen J. Jejeebhoy, Vijaya Nidadavolu, K.G. Santhya, William Finger, Shyam Thapa, Iqbal Shah, and Ina Warriner. "The adverse health and social outcomes of sexual coercion: Experiences of young women in developing countries," research brief. New Delhi: Population Council.

"Forced sexual relations among married young women in developing countries," research brief. New Delhi: Population Council.

"Sexual coercion: Young men's experiences as victims and perpetrators," research brief. New Delhi: Population Council.

Kunene, Busi, Mags Beksinka, Simphiwe Zondi, Nobuhle Mthembu, Saiqa Mullick, Emma Ottolenghi, Immo Kleinschmidt, Susan Adamchak, Barbara Janowitz, and Carmen Cuthbertson. "Involving men in maternity care: South Africa," FRONTIERS Final Report. Washington, DC: Population Council.

Lhungdim, Hemkhothang and Ravi K. Verma. "Sexual behaviour of male youth in rural India: A five-state study," in T.K. Roy, M. Guruswamy, and P. Arokiasamy (eds.), Population, Health and Development in India: Changing Perspectives. Jaipur: IIPS Mumbai/Rawat Publications.

"Masculinity and sexual risk behaviour among young men in Mumbai slums," research brief. New Delhi: Population Council.

Panda, Pradeep Kumar. "Domestic violence against women in Kerala," Kerala Research Program on Local Level Development Discussion Paper no. 86. Kerala, India: Centre for Development Studies.

Sabir, Ahmed Al, Mohammed Ahsanul Alam, Sharif Mohammed Ismail Hossain, Ubaidur Rob, and M.E. Khan. "Integration of reproductive health services for men in health and family welfare centers in Bangladesh," FRONTIERS Final Report. Washington, DC: Population Council.

Sholkamy, Hania and Farha Ghannam (eds.). Health and Identity in Egypt: Shifting Frontiers. Cairo: American University in Cairo Press.

\section{HIV/AIDS}

"Access to antiretroviral treatment: What role can health insurance play in India?" research brief. New Delhi: Population Council.

"Access to antiretrovirals in India: A feasibility study," report of the HIV/STI Prevention and Care Research Programme. New Delhi: Population Council.

"Addressing masculinity as a strategy to reduce HIV/AIDS related risky sexual behavior among young men in Mumbai: Formative research leading to the development of intervention package," report of the HIV/STI Prevention and Care Research Programme. New Delhi: Population Council.

Bhuiya, Ismat, Ubaidur Rob, Nazia Yusuf, and Asiful Haidar Chowdhury. "South Asia political advocacy project: Bangladesh database on HIV/AIDS." Dhaka: Population Council and UNAIDS.
"Case management of reproductive tract infections in India: An analysis of clinical protocols and cost at primary care clinics in New Delhi," report of the HIV/STI Prevention and Care Research Programme. New Delhi: Population Council.

"A cross-sectional study on sexual behaviour and the prevalence of HIV and other STIs among injecting drug users and their sexual partners," research brief. New Delhi: Population Council.

"Estimating the prevalence of HIV infection and other STDs among injecting drug users and their sexual partners in Chennai: A cross-sectional study," report of the HIV/STI Prevention and Care Research Programme. New Delhi: Population Council.

"Formative research to identify protective and risk factors for the sexual transmission of HIV and STIs among injecting drug users and their partners," research brief. New Delhi: Population Council.

"Formative research leading to the development of an intervention to reduce the risk of sexual transmission of HIV and STIs among drug users and their female partners in Chennai, India," report of the HIV/STI Prevention and Care Research Programme. New Delhi: Population Council.

Hallman, Kelly. "Socioeconomic disadvantage and unsafe sexual behaviors among young women and men in South Africa," Policy Research Division Working Paper no. 190. New York: Population Council. Horizons Program, Makerere University Department of Sociology, and Plan Uganda. "Succession planning in Uganda: Early outreach for AIDS-affected children and their families," Horizons Final Report. Washington, DC: Population Council.

Horizons Program, International Centre for Reproductive Health, and Coast Province General Hospital, Mombasa. Adherence to Antiretroviral Therapy in Adults: A Guide for Trainers. Nairobi: Population Council.

"Improving care for people living with HIV/AIDS through training and support for private practitioners: Findings from a pilot intervention research project," report of the HIV/STI Prevention and Care Research Programme. New Delhi: Population Council.

"Improving clinical care for people living with HIV/AIDS: A comprehensive training approach," research brief. New Delhi: Population Council.

Macintyre, Kate, Naomi Rutenberg, Lisanne Brown, and Ali Karim. "Understanding perceptions of HIV risk among adolescents in KwaZulu-Natal," AIDS and Behavior 8(3): 237-250.

McCauley, Ann. "Equitable access to HIV counseling and testing for youth in developing countries: A review of current practice," Horizons Report. Washington, DC: Population Council.

McCauley, Ann, Milka Juma, Edward Kirumira, Nelson Kakande, Scott Geibel, C. Hitimana-Lukanika, Daniel Lukenge, and Edith Mukisa. "Attracting youth to voluntary counseling and testing services in Uganda," Horizons Research Summary. Washington, DC: Population Council.

Ndhlovu, Lewis, Catherine Searle, and Johannes van Dam. "Strengthening STI treatment and HIV/AIDS prevention services in Carletonville, South Africa," Horizons Research Summary. Washington, DC: Population Council.

continued on page $7 \mathrm{~A}$

Publications are by Population Council staff members, consultants, or staff from partner organizations. Year of publication is 2004 unless otherwise noted. Names in boldface are staff members or those from partner organizations. 
Ogden, Jessica, Simel Esim, and Caren Grown.

"Expanding the care continuum for HIV/AIDS: Bringing carers into focus," Horizons Final Report. Washington, DC: Population Council and International Center for Research on Women.

Panpanich, Ratana et al. "A rapid situation analysis of the access to care project in northern Thailand," Horizons Final Report. Washington, DC: Population Council.

"A physician training model for improving HIV clinical care," report of the HIV/STI Prevention and Care Research Programme. New Delhi: Population Council.

Pistorius, Annalie G., Janneke H.H.M. van de Wijgert, Mohlatlego Sebola, Barbara A. Friedland, Evelyn Nagel, Cathleen Bokaba, and Anwar A. Hoosen. "Microbicide trials for preventing HIV/AIDS in South Africa: Phase II trial participants' experiences and psychological needs," Journal of Social Aspects of HIV/AIDS 1(2): 78-86.

Pope, Melissa. "Early dendritic cell-driven events governing the mucosal transmission of HIV: Targets for vaccines and microbicides." International AIDS Vaccine Initiative Report 8(2): 1-5.

"Quality of care by rural private providers in north India for reproductive tract infections including sexually transmitted ones," report of the HIV/STI Prevention and Care Research Programme. New Delhi: Population Council.

Ramakrishna, Jayashree, Pertti J. Pelto, Ravi K. Verma Stephen L. Schensul, and Archana Joshi. "Guidelines for policy-making and interventions in the time of AIDS." in Ravi K. Verma, Pertti J. Pelto, Stephen L. Schensul, and Archana Joshi (eds.), Sexuality in the Time of AIDS: Contemporary Perspectives from Communities in India. New Delhi: SAGE Publications.

Sarna, Avina, Susan Kaai, and Mark Hawken. "Acceptability of a modified directly observed therapy approach to improve adherence to antiretroviral therapy," Horizons Research Summary. Washington, DC: Population Council.

Schensul, Stephen L., Ravi K. Verma, Pertti J. Pelto, and Archana Joshi. "Multi-method approaches to research on sexuality in the time of AIDS," in Ravi K. Verma, Pertti J. Pelto, Stephen L. Schensul, and Archana Joshi (eds.), Sexuality in the Time of AIDS: Contemporary Perspectives from Communities in India. New Delhi: SAGE Publications

"STI/RTI research methods in India: Problems and solutions," workshop report of the HIV/STI Prevention and Care Research Programme. New Delhi: Population Council.

Verma, Ravi K. and Martine Collumbien. "Homosexual activity among rural Indian men: Implications for HIV interventions," AIDS 18(13): 1845-1847.

Verma, Ravi K. and Hemkhothang Lhungdim. "Sexuality and sexual behaviours in rural India: Evidence from a five-state study," in Ravi K. Verma, Pertti J. Pelto, Stephen L. Schensul, and Archana Joshi (eds.), Sexuality in the Time of AIDS: Contemporary Perspectives from Communities in India. New Delhi: SAGE Publications.

Verma, Ravi K., Pertti J. Pelto, Stephen L. Schensul, and Archana Joshi (eds.). Sexuality in the Time of AIDS: Contemporary Perspectives from Communities in India. New Delhi: SAGE Publications.

"Introduction: The time of AIDS in India," in

Ravi K. Verma, Pertti J. Pelto, Stephen L. Schensul, and Archana Joshi (eds.), Sexuality in the Time of AIDS: Contemporary Perspectives from Communities in India. New Delhi: SAGE Publications.
"Variations in sexual behaviour in the time of AIDS," in Ravi K. Verma, Pertti J. Pelto, Stephen L. Schensul, and Archana Joshi (eds.), Sexuality in the Time of AIDS: Contemporary Perspectives from Communities in India. New Delhi: SAGE Publications.

Verma, Ravi K. and Stephen L. Schensul. “Male sexua health problems in Mumbai: Cultural constructs that present opportunities for HIV/AIDS risk education." in Ravi K. Verma, Pertti J. Pelto, Stephen L. Schensul, and Archana Joshi (eds.), Sexuality in the Time of AIDS: Contemporary Perspectives from Communities in India. New Delhi: SAGE Publications.

"Vulnerability and intervention opportunities: Research findings on youth and HIV/AIDS in South Africa," Horizons Research Update. Washington, DC Population Council.

\section{Quality of Care}

“La estrategia de consejería balanceada: Mejorando la calidad para los clientes" [The balanced counseling strategy: Improving quality of care for clients], FRONTIERS Program Report no. 3. Mexico City: Population Council.

Himelfarb, Elaine C. “Improving health care providers' knowledge, attitudes, and practices in reproductive health in rural Romania," FRONTIERS Final Report. Washington, DC: Population Council.

Nawar, Laila, Ibrahim Kharboush, Magdi A. Ibrahim, Hesham Makhlouf, and Susan Adamchak. "Impact of improved client-provider interaction on women's achievement of fertility goals in Egypt," FRONTIERS Final Report. Washington, DC: Population Council.

\section{Reproductive Health}

"Afrique du Sud: Qui utilise les centres de jeunes et pourquoi?" [South Africa: Who uses youth centers and why?], FRONTIERS OR Summary no. 23. Dakar:

Population Council.

Askew, lan, Jane Chege, Carolyne Njue, and Samson Radeny. "A multi-sectoral approach to providing reproductive health information and services to young people in Western Kenya: The Kenya adolescent reproductive health project," FRONTIERS Final Report.

Washington, DC: Population Council.

"Bangladesh: Offering reproductive health services for men improves clinic utilization," FRONTIERS OR Summary no. 47. Washington, DC: Population Council.

“Bangladesh: Relier les ressources sur la santé de la reproduction des adolescents afin d'accroître l'accès" [Bangladesh: Link adolescent reproductive health resources to increase access], FRONTIERS OR Summary no. 34. Dakar: Population Council.

Barge, Sandhya, Hillary Bracken, Batya Elul, Nayan Kumar, Wajahat U. Khan, Shalini Verma, and Carol Camlin. "Formal and informal abortion services in Rajasthan, India: Results of a situation analysis." New Delhi: Population Council.

Bhuiya, Ismat, Ubaidur Rob, Asiful Haidar Chowdhury Laila Rahman, Nazmul Haque, Susan Adamchak, Rich Homan, and M.E. Khan. "Improving adolescent reproductive health in Bangladesh." Dhaka: Population Council.

Bratt, John, Nahla Abdel-Tawab, and Magdi Abdel Kader. "Validation of a survey-based approach for predicting willingness-to-pay for reproductive health services," FRONTIERS Project Update no. 1. Cairo: Population Council.

Budiharsana, Meiwita, Lila Amaliah, Budi Utomo, and Erwinia. “Female circumcision in Indonesia: Extent, implications and possible interventions to uphold women's health rights." Jakarta: Population Council.
"Care for RTIs/STIs through informal rural health care providers: Time to change practice," research brief. New Delhi: Population Council.

Center for Research on Environment, Health, and Population Activities. "Determining an effective and replicable communication-based mechanism for improving young couples' access to and use of reproductive health information and services in Nepal: An operations research study," FRONTIERS Final Report Washington, DC: Population Council.

Chege, Jane, lan Askew, Susan Igras, and Jacinta K. Mutesh. "Testing the effectiveness of integrating community-based approaches for encouraging abandonment of female genital cutting into CARE's reproductive health programs in Ethiopia and Kenya," FRONTIERS Final Report. Washington, DC: Population Council.

Cherine, Mohamed, Karima Khalil, Nevine Hassanein, Hania Sholkamy, Miral Breebaart, and Amr Elnoury. "Management of the third stage of labor in an Egyptian teaching hospital," International Journal of Gynecology and Obstetrics 87(1): 54-58.

Diop, Nafissatou J., Heli Bathidja, Isseu Diop Touré, Thierno Dieng, Babacar Mané, Saumya RamaRao, Susan Adamchak, Emelita Wong, Colonel Adama Ndoye, Aboubacry Sy, and Babacar Fall. "Improving the reproductive health of adolescents in Senegal," FRONTIERS Final Report. Washington, DC: Population Council.

Diop, Nafissatou J., Modou Mbacke Faye, Amadou Moreau, Jacqueline Cabral, Hélène Benga, Fatou Cissé, Babacar Mané, Inge Baumgarten, and Molly Melching. "The Tostan program: Evaluation of a community-based education program in Senegal," FRONTIERS Final Report. Washington, DC: Population Council.

Elul, Batya, Sandhya Barge, Shalini Verma, Nayan Kumar, Hillary Bracken, and Hemlata Sadhvani. "Unwanted pregnancy and induced abortion: Data from men and women in Rajasthan, India." New Delhi: Population Council.

Elul, Batya, Hillary Bracken, Shalini Verma, Rajani Ved, Rajesh Singhi, and Karin Lockwood. “Unwanted pregnancy and induced abortion in Rajasthan, India: A qualitative exploration." New Delhi: Population Council.

"Emplear a hombres como distribuidores comunitarios de condones" [Using men as community-based distributors of condoms], FRONTIERS Program Report no. 2. Mexico City: Population Council.

Fikree, Fariyal F., Sadiqua N. Jafarey, Razia Korejo, A. Khan, and Jill M. Durocher. "Pakistani obstetricians' recognition of and attitude towards domestic violence screening," International Journal of Gynecology and Obstetrics 87(1): 59-65.

Foundation for Research in Health Systems. "Community involvement in reproductive health: Findings from research in Karnataka, India," FRONTIERS Final Report. Washington, DC: Population Council.

Guatemalan Association of Female Physicians. "Scaling up a successful counseling model in Guatemala," FRONTIERS Final Report. Washington, DC: Population Council.

Huntington, Dale, Mary Philip Sebastian, Barbara Mensch, Wesley Clark, Aditya Narain Singh, Sohini Roychowdhury, M.E. Khan, Nirmala Selvam, Bella Patel, Sandhya Barge, Y.P. Gupta, Lovleen Johri, Gita Biswas, and Manohar Shenoy. "Integrating adolescent livelihood activities within a reproductive health program for urban slum dwellers in India," FRONTIERS Final Report. Washington, DC: Population Council. Jejeebhoy, Shireen J. (ed.). Looking Back, Looking Forward: A Profile of Sexual and Reproductive Health in India. Jaipur: Population Council/Rawat Publications. 
Jejeebhoy, Shireen J. and K.G. Santhya. "Looking back, looking forward," in Shireen J. Jejeebhoy (ed.), Looking Back, Looking Forward: A Profile of Sexual and Reproductive Health in India. Jaipur: Population Council/Rawat Publications, pp. 183-185.

Jejeebhoy, Shireen J., K.G. Santhya, Ravi K. Verma, Leila Caleb Varkey, Vaishali Sharma Mahendra, Anjali Widge, Vijaya Nidadavolu, and Deepika Ganju. “Setting the stage," in Shireen J. Jejeebhoy (ed.), Looking Back, Looking Forward: A Profile of Sexual and Reproductive Health in India. Jaipur: Population Council/Rawat Publications, pp. 3-22.

Jejeebhoy, Shireen J. and Mary Philip Sebastian "Young people's sexual and reproductive health," in Shireen J. Jejeebhoy (ed.), Looking Back, Looking Forward: A Profile of Sexual and Reproductive Health in India. Jaipur: Population Council/Rawat Publications, pp. 138-168.

Jejeebhoy, Shireen J. and Leila Caleb Varkey. “Maternal health and pregnancy-related care," in Shireen J. Jejeebhoy (ed.), Looking Back, Looking Forward: A Profile of Sexual and Reproductive Health in India. Jaipur: Population Council/Rawat Publications, pp. 44-87. Kestler, Edgar and Lilian Ramirez. "Informing the medical community in Guatemala about emergency contraception," FRONTIERS Final Report. Washington, DC: Population Council.

Khalil, Karima and Farzaneh Roudi-Fahimi. “Making motherhood safer in Egypt." Washington, DC: Population Reference Bureau.

León, Federico R. and Mary L. Claux. "Youth behavioral risks and psychosocial resources in Peru's alternativedevelopment zones," FRONTIERS Final Report. Washington, DC: Population Council.

Martin, Antonieta. “La anticoncepción de emergencia en América Latina y el Caribe" [Emergency contraception in Latin America and the Caribbean], Revista Panamericana de Salud Pública 16(6): 424-431.

"Medicalization of FGC among the Abagusii, Kenya," Africa Region Research Summary. Nairobi: Population Council.

“Mexique: Renforcer l'éducation sur la santé de la reproduction des adolescents" [Mexico: Strengthen education on adolescent reproductive health], FRONTIERS OR Summary no. 36. Dakar: Population Council.

Nidadavolu, Vijaya. “Domestic violence," in Shireen J. Jejeebhoy (ed.), Looking Back, Looking Forward: A Profile of Sexual and Reproductive Health in India. Jaipur: Population Council/Rawat Publications, pp. 169-179.

Njue, Carolyne and lan Askew. "Medicalization of female genital cutting among the Abagusii in Nyanza Province, Kenya," FRONTIERS Final Report.

Washington, DC: Population Council.

Ouoba, Djingri, Zakari Congo, Nafissatou J. Diop, Molly Melching, Baya Banza, Georges Guiella, and Inge Baumgarten. “Experience from a community-based education program in Burkina Faso: The Tostan program," FRONTIERS Final Report. Washington, DC: Population Council.

Population Council, Islamabad. Unwanted Pregnancy and Post-Abortion Complications in Pakistan: Findings from a National Study. Islamabad: Population Council.

Santhya, K.G. “Changing family planning scenario in India," Regional Health Forum, WHO South-East Asia Region 8(1): 68-83.

"Contraceptive use dynamics," in Shireen J. Jejeebhoy (ed.), Looking Back, Looking Forward: A Profile of Sexual and Reproductive Health in India. Jaipur: Population Council/Rawat Publications, pp. 25-43.
"Reproductive tract and sexually transmitted infections," in Shireen J. Jejeebhoy (ed.), Looking Back Looking Forward: A Profile of Sexual and Reproductive Health in India. Jaipur: Population Council/Rawat Publications, pp. 114-137.

Santhya, K.G. and Shalini Verma. "Induced abortion," in Shireen J. Jejeebhoy (ed.), Looking Back, Looking Forward: A Profile of Sexual and Reproductive Health in India. Jaipur: Population Council/Rawat Publications, pp. 88-104.

"Scaling up a multi-sectoral pilot project," FRONTIERS Research Update. Nairobi: Population Council.

"Understanding induced abortion: Findings from a programme of research in Rajasthan, India," research brief. New Delhi: Population Council.

"Understanding the practice of female genital cutting among the Somali of Kenya, and the management of its complications," Africa Region Research Summary. Nairobi: Population Council.

Vernon, Ricardo and Maricela Durá. "Improving the reproductive health of youth in Mexico," FRONTIERS Final Report. Washington, DC: Population Council.

"West Bank and Gaza: Promote awareness of the benefits of women's reproductive health," FRONTIERS OR Summaryno. 46. Washington, DC: Population Council.

“Zambie: Les pairs éducateurs peuvent contribuer à la promotion de comportements sexuels moins risqués" [Zambia: Peer educators can promote safer sex behaviors], FRONTIERS OR Summary no. 17. Dakar:

Population Council.

\section{Social Science}

Awoonor-Williams, John Koku, Ellie S. Feinglass, Rachel Tobey, Maya N. Vaughan-Smith, Frank K. Nyonator, and Tanya C. Jones. "Bridging the gap between evidence-based innovation and national health-sector reform in Ghana," Studies in Family Planning 35(3): 161-177 (also published as Policy Research Division Working Paper no. 191. New York: Population Council)

Bongaarts, John. "Long-range trends in adult mortality: Models and projection methods," Policy Research Division Working Paper no. 192. New York: Population Council.

Demeny, Paul. “Population futures for the next three hundred years: Soft landing or surprises to come?" Population and Development Review 30(3): 507-517.

Freedman, Vicki A., Eileen Crimmins, Robert F. Schoeni, Brenda C. Spillman, Hakan Aykan, Ellen Kramarow, Kenneth Land, James Lubitz, Kenneth Manton, Linda G. Martin, Diane Shinberg, and Timothy Waidmann.

"Resolving inconsistencies in trends in old-age disability: Report from a technical working group," Demography 41(3): 417-441.

Hewett, Paul C., Barbara Mensch, and Annabel S Erulkar. "The feasibility of computer-assisted survey interviewing in Africa: Experience from two rural districts in Kenya," Social Science Computer Review 22(3): 319-334 (also published as Policy Research Division Working Paper no. 168. New York: Population Council, 2003).

Jain, Anrudh. “Role of research on policy development implementation," in Population Research and Policy Development in Pakistan, proceedings of the Fourth Annual Research Conference of the Population Association of Pakistan, 9-11 December 2003, Faisalabad. Islamabad: Population Association of Pakistan.
McNicoll, Geoffrey. “Demographic future of East Asian regional integration," in T.J. Pempel (ed.), Remapping East Asia: The Construction of a Region. Ithaca: Cornell University Press (also published as Policy Research Division Working Paper no. 158. New York: Population Council, 2002)

Review of Alberto Alesina and Enrico Spolaore, The Size of Nations, Population and Development Review 30(1): 168-170.

. Review of Peter Singer, One World: The Ethics of Globalization, Population and Development Review 30(3): 552-555.

\section{Strengthening Local Resources}

Assal, Munzoul A.M. "Displaced persons in Khartoum: Current realities and post-war scenarios," MEAwards report. Cairo: Population Council.

Health, Development, Information and Policy Institute. 2004. "Institutional support for a program of activities within the pilot health project in the West Bank and Gaza," FRONTIERS Final Report. Washington, DC: Population Council.

\section{Transitions to Adulthood}

Arends-Kuenning, Mary and Sajeda Amin. “School incentive programs and children's activities: The case of Bangladesh," Comparative Education Review. 48(3): 295-317.

Brown, Lisanne, Kate Macintyre, Anthea Dallimore, and Robert Magnani. "Secondary school principals report dramatic expansion of life skills," Horizons Research Summary. Washington, DC: Population Council.

Bruce, Judith and Shelley Clark. "The implications of early marriage for HIV/AIDS policy," brief. New York: Population Council.

Colom, Alejandra, Marta Julia Ruiz, Jennifer Catino, Kelly Hallman, Sara Peracca, and Kristen M. Shellenberg. "Voices of vulnerable and underserved adolescents in Guatemala. A summary of the qualitative study 'Understanding the Lives of Indigenous Young People in Guatemala.'" Guatemala City: Population Council.

El Gibaly, Omaima M.H. and Susan M. Lee-Rife. Too Young to Be a Mother: A Description of the Lives of Married Adolescent Girls in Egypt. Cairo: Population Council.

Hewett, Paul, Barbara S. Mensch, and Annabel S. Erulkar. "Consistency in the reporting of sexual behaviour by adolescent girls in Kenya: A comparison of interviewing methods," Sexually Transmitted Infections 80(suppl 2): ii43-ii48 (also published as Policy Research Division Working Paperno. 182. New York: Population Council, 2003).

Mensch, Barbara S., Monica Grant, Mary Philip Sebastian, Paul Hewett, and Dale Huntington. "The effect of a livelihoods intervention in an urban slum in India: Does vocational counseling and training alter the attitudes and behavior of adolescent girls? Policy Research Division Working Paper no. 194. New York: Population Council.

Ritchie, Amanda, Cynthia B. Lloyd, and Monica Grant. "Gender differences in time use among adolescents in developing countries: The implications of rising school enrollment rates," Policy Research Division Working Paperno. 193. New York: Population Council. 
12 Population Council

One Dag Hammarskjold Plaza, New York, NY 10017

Population Briefs is a research newsletter of the Population Council. The Council is an international, nonprofit, nongovernmental organization that seeks to improve the well-being and reproductive health of current and future generations around the world and to help achieve a humane, equitable, and sustainable balance between people and resources. The Council conducts biomedical social science, and public health research and helps build research capacities in developing countries. Established in 1952, the Council is governed by an international board of trustees. Its New York headquarters supports a global network of regional and country offices.

Writer/Editor Copyeditor

Gina Duclayan Robert Heidel

Production Manager Editorial Assistant

Y. Christina Tse Jared Stamm

Production Artist Circulation

Sura Rosenthal Debra Warn

Population Briefs is distributed without charge. Information in this newsletter may be reproduced without permission, provided it is distributed with-

out charge and the source is acknowledged.

To receive e-mail when a new issue of Population Briefs is posted to the Population Council Web site, register at www.popcouncil.org/signup

ISSN 1084-6786

(C2005 The Population Council, Inc.

\section{IN THIS ISSUE}

MATERNAL AND CHILD HEALTH

"Involving men in maternal care is something that couples want, both men and women."

See page 1
Despite well-documented progress in health and an acknowledged improvement in child mortality rates, many rural Bengalis firmly believe that adult health and survival have declined in recent years.

\section{HIVIAIDS}

"The data show that a wide range of risky behaviors is affected by poverty."

See page 3

\section{SAFE MOTHERHOOD}

"Harmless traditional practices can be encouraged in counseling sessions and through information dissemination, and risky ones discouraged. In this way we can maintain traditions in a healthier way." 